\title{
LITERATURA BRASILEIRA E DRAMATURGIA NACIONAL: FRONTEIRAS E PASSAGENS
}

\author{
BRAZILIAN LITERATURE AND DRAMATURGY: \\ BORDERS AND CROSSINGS
}

\begin{abstract}
André Dias $^{1}$
RESUMO: O presente artigo discute a situação das fronteiras e passagens da literatura brasileira e da dramaturgia nacional. A ênfase do estudo recai sobre a necessidade promover uma aproximação entre o universo do teatro nacional e da literatura brasileira nas licenciaturas de Letras do país. Como amostra da profícua aproximação, ao longo do trabalho foram empreendidas análises das peças: O noviço, de Martins Pena, Auto da compadecida, de Ariano Suassuna e Eles não usam black-tie, de Gianfrancesco Guarnieri.
\end{abstract}

PALAVRAS-CHAVE: teatro nacional; literatura brasileira; análise de discursos; cultura brasileira.

\begin{abstract}
This paper aims to discuss the situation of the borders between Brazilian literature and dramaturgy. We will emphasize the need to promote a connection between Brazilian dramaturgy and Brazilian literature in undergraduate courses in Brazil. As a case study, we have analysed the following plays: $O$ noviço, by Martins Pena, Auto da compadecida, by Ariano Suassuna and Eles não usam black-tie, by Gianfrancesco Guarnieri.
\end{abstract}

KEYWORDS: Brazilian Dramaturgy; Brazilian Literature; Discourse Analysis; Brazilian culture.

É possível falarmos em uma separação irreconciliável entre a Literatura Brasileira e a dramaturgia nacional? O conjunto de obras que formam o cânone da Literatura Brasileira abarca uma multiplicidade de gêneros, por que, então, a maioria das histórias da Literatura Brasileira negligenciam ou apenas abordam superficialmente o discurso dramatúrgico? Tal problema se avoluma quando questionado, por exemplo, o lugar ocupado pelo estudo da dramaturgia, especialmente a brasileira, nos cursos de Letras pelo país afora. Sobre essa questão afirma João Roberto Faria:

Com poucas exceções, a dramaturgia é estudada com parcimônia, como se fosse mero apêndice da nossa história literária. Por vezes, nem mesmo é levada em conta nos programas da disciplina Literatura Brasileira. A exigência de um instrumental teórico e

\footnotetext{
${ }^{1}$ Universidade Federal Fluminense - UFF, Programa de Pós-Graduação em Estudos de Literatura, Departamento de Línguas Vernáculas, Niterói, Rio de Janeiro, Brasil; https://orcid.org/0000-0003-2114-7768 ; andredias@id.uff.br 
analítico próprio, que nem sempre é do domínio de quem estuda a poesia e a prosa, e o diálogo dos nossos dramaturgos com seus pares europeus e norte-americanos - o que exige conhecimento de suas obras - são dificuldades que afastam professores de Literatura Brasileira da dramaturgia. (Faria, 2013, p. 504 -505)

As considerações do crítico dão conta do lugar periférico ocupado pelos estudos da dramaturgia nos cursos de Letras no país. Suas observações realçam também possíveis dificuldades práticas enfrentadas por parte dos estudiosos oriundos da área de Literatura. Como exemplo, o pesquisador cita a pouca intimidade com um instrumental teórico apropriado ao texto teatral ou a limitada leitura de obras dramatúrgicas nacionais e estrangeiras. Os apontamentos de Faria, de certo modo, põem em relevo a natureza dissonante daqueles que a partir da ótica da Literatura se ocupam em pesquisar a dramaturgia em suas variadas possibilidades.

À primeira vista, estudar o discurso dramatúrgico no campo dos estudos literários pode soar como uma transgressão de fronteiras entre as áreas do conhecimento. Ou seja, em certo sentido, a dramaturgia parece pertencer exclusivamente aos domínios das Artes Cênicas, pois o teatro é uma arte autônoma, que até pode ser realizada prescindindo do texto e, por isso, pode restringir-se ao universo da encenação. Contudo, o problema aqui não é o da demarcação territorial dos campos do conhecimento, mas a busca pela aproximação, o trânsito e a superação das fronteiras arbitrariamente estabelecidas. Em estudo intitulado "O Fenômeno Teatral", Anatol Rosenfeld encontra uma solução consensual satisfatória para a questão da feição híbrida do discurso dramatúrgico:

O que importa verificar é que a peça como tal, quando lida e mesmo recitada, é literatura; mas quando representada, passa a ser teatro. Trata-se de duas artes diferentes, por maior que possa ser a sua interdependência. A literatura teatral vira teatro literário; o que era substantivo passa a ser adjetivo, o que era substância torna-se acidente. Não é jogo de palavras. (Rosenfeld, 1985, p. 24)

As ponderações de Rosenfeld conseguem equacionar de modo bastante didático o problema da dicotomia do discurso dramatúrgico. Desse ponto de vista, o estabelecimento dos limites claros entre literatura e teatro ajuda aos pesquisadores que se ocupam dos textos dramáticos. Apesar de esclarecedora e útil, a separação com fins didáticos entre o universo do teatro e o mundo da literatura deve sempre ser encarada com parcimônia, para que a investigação sobre o tema não corra o risco de ser engessada em limites estanques. A riqueza do trabalho com o discurso teatral reside exatamente nesse jogo de ambivalências, em que o pesquisador deve simultaneamente concentrar seu olhar na análise da obra dramatúrgica enquanto materialidade literária sem, necessariamente, abrir mão de confrontar a investigação do objeto literário com o fenômeno cênico advindo da montagem de um texto dramático.

Aos estudiosos que decidirem enveredar pelos caminhos da análise da dramaturgia brasileira é recomendável que adotem um procedimento investigativo que lance mão tanto da análise de textos dramatúrgicos, quanto das encenações que constituem uma interpretação dessas obras. Tal escolha se deve primordialmente à riqueza de avaliações que podem emergir do entrecruzamento do discurso dramatúrgico com a palavra encarnada nas encenações. Para melhor compreender essa escolha, vale a pena retornar aos apontamentos de Anatol Rosenfeld:

Tornou-se claro que o teatro é uma arte bem diversa da literatura. Se na literatura a palavra é fonte da personagem, no teatro a personagem é fonte da palavra, graças à metamorfose do ator em ser fictício. No palco, a personagem já "fala" antes de pronunciar a primeira 
palavra. O silêncio do grande ator pode ser mais eloquente do que centenas de palavras, enquanto na literatura o próprio silêncio tem de ser mediado por palavras. (Rosenfeld, $1985,35-36)$

As apreciações do crítico sobre os papeis da palavra para a literatura e para o teatro iluminam a percepção da importância de se estudar o discurso dramatúrgico em consonância com as possíveis encenações dele advindas. Além disso, acreditamos que ler a obra teatral em diálogo estreito com suas encenações amplia as possibilidades de interpretação e compreensão dos usos que as palavras ganham na relação: dramaturgia/encenação. Contudo, para a plena execução de tal procedimento investigativo é fundamental que o pesquisador tenha clareza sobre a necessidade de construir um repertório cultural amplo, que englobe o discurso literário, mas que não se restrinja a ele. Em outras palavras, o estudioso do discurso dramatúrgico precisa ser um leitor em um sentido ampliado. Além de ler o escrito, é preciso também desenvolver a habilidade da leitura do visual e do verbo-visual nas mais diferentes modalidades.

No que diz respeito aos estudos da dramaturgia de modo geral, e da brasileira em particular, a construção de um repertório artístico alargado, que abranja um conhecimento mínimo satisfatório sobre os elementos constituintes do universo teatral será determinante para a consolidação de uma análise consistente e ampla do discurso dramatúrgico. Um exemplo simples, mas de grande relevância para o campo dos estudos da dramaturgia, está presente na compreensão do papel da didascália ou rubrica para o desenvolvimento de uma peça. Entender que as rubricas são indicações cênicas feitas pelos dramaturgos para marcarem como determinada ação, como determinada cena, como determinado espaço ou como determinada fala devem ser feitos em uma peça de teatro faz toda a diferença nos modos de apropriação de uma obra dramática. O leitor de uma peça ao acompanhar e analisar detidamente as marcações feitas pelo dramaturgo em uma obra será capaz de perceber os efeitos de sentido pretendidos pelo autor no desenvolvimento da narrativa. Já o espectador de um espetáculo teatral que tenha lido o texto em encenação, será capaz de confrontar as rubricas do autor com as marcações desenvolvidas pelo diretor/encenador em uma montagem específica. Tal habilidade não deve ser vista como mero exercício de diletantismo, mas como uma etapa fundamental no processo de formação de um leitor competente da experiência verbo-visual que envolve o trabalho com o teatro.

Poderia me deter a falar ainda sobre aspectos concernentes à cenografia, ao figurino, à música, à preparação corporal de atrizes e atores e, claro, do trabalho de direção e interpretação do texto teatral, elementos determinantes para uma recepção satisfatória de uma encenação. Contudo, nesse momento, gostaria de me concentrar, nas possibilidades e riquezas literárias das obras dramatúrgicas. Essas, quando exploradas no ambiente das salas de aula, trazem uma incontornável contribuição para a ampliação do repertório cultural, artístico, social e humanístico de alunos e professores que se permitem navegar por esse rico universo de águas quase nunca mansas, repletas de obstáculos, mas capazes de nos encaminhar para outro lugar, sempre distante da inoperância de uma existência inerte. Nesse sentido, considero muito pertinente empreender uma análise de uma amostra significativa do teatro brasileiro, a fim de compreendermos como a dramaturgia nacional pode colocar um país em cena.

Comecemos pelo trabalho de Martins Pena, fundador da comédia de costumes no país, autor de trajetória curta, porém prolífica. Pena produziu vinte comédias e seis dramas, dos 22 aos 33 anos, quando morreu acometido pela tuberculose. Seu talento e relevância para a dramaturgia nacional foram reconhecidos por críticos do quilate de Silvio Romero e José Veríssimo, ainda em fins do século XIX, início do XX. O primeiro salientava o valor documental dos escritos do dramaturgo, destacando a espontaneidade com a qual operava $\mathrm{o}$ jovem escritor na construção de notáveis painéis da sociedade da época. Já o segundo, movido

Rev. Bras. Lit. Comp. Niterói, v. 22, n. 39, pp. 148-161, jan. /abr. 2020 
por uma visão excessivamente estetizante, considerava Martins Pena um escritor capaz de produzir histórias que não sobreviveriam para além do palco. Apesar da dura apreciação de Veríssimo sobre o trabalho do comediógrafo - em se tratando do renomado crítico, nenhuma novidade quando o assunto era teatro, em texto de 1901 afirmava o estudioso: “... o teatro propriamente fluminense no Rio de Janeiro caiu numa pulhice intolerável para toda a pessoa simplesmente decente." (Veríssimo, 2001, p. 234) -, esse soube também reconhecer o valor histórico e documental das comédias do dramaturgo.

Vilma Arêas em estudo decisivo sobre a obra do escritor destaca o caráter político de seu teatro, sobretudo quando lido pela posteridade:

Não será exagero afirmar a vocação política desse teatro, que não tem nenhuma semelhança com as regras sobre modelos de conduta. Ele está além dessa ingenuidade, como, com extrema malícia, escapole da dicotomia simples do certo e do errado na análise de seus tipos. (Arêas, p. 1987, 178)

Não é redundante lembrar que a dramaturgia de Martins Pena se desenvolve ao longo do primeiro influxo romântico brasileiro. Gonçalves de Magalhães, por exemplo, publica em 1836 Suspiros poéticos e saudades, considerada a obra inaugural do Romantismo no país. O período inicial do Romantismo, como sabemos, foi marcado pelo esforço de construir uma concepção de identidade nacional. Tal esforço encontrou nos romances de José de Alencar e na poesia de Gonçalves Dias seus momentos mais luminosos e idealizados. Descolados do país concreto, os principais escritores do romantismo brasileiro idealizaram um nacionalismo de feição um tanto edulcorada e desencarnado dos principais conflitos presentes no tecido social brasileiro da época. Nesse sentido, sobretudo aos olhos do presente, o teatro de Martins Pena assume um caráter político. Esse caráter, pode ser aferido a partir da escolha do autor em trabalhar com o gênero teatral da comédia. Ao operar nas searas da comédia o dramaturgo colocou em cena os tipos humanos que povoavam os diversos espaços públicos e privados do país sem, no entanto, ceder à tentação de plasmar em suas obras virtudes exemplares, antes ressaltando o caráter errático presente nos mais variados extratos sociais do país. Nesse sentido, a dramaturgia de Martins Pena assume a vocação política sacada com precisão por Vilma Arêas.

Sábato Magaldi ao avaliar a obra do comediógrafo sinaliza a pertinência da produção para os dias de hoje.

A espantosa atualidade de Martins Pena permanece, assim, um lugar-comum, sempre vitalizado por uma ou outra encenação bem recebida. Admirável observador, ele fixou costumes e características que têm continuado através do tempo, e retratam as instituições nacionais. Retrato melancólico e primário, sem dúvida, mas exuberante de fidelidade. Em pleno surto do movimento romântico, idealizador de um nacionalismo róseo, Martins Pena antecipa, com noção precisa, alguns dos nossos traços dominantes, ainda que menos abonadores. (Magaldi, 2004, p. 42 - 43).

As postulações de Magaldi e Arêas apresentam pontos de contato. Essa, como já apontado, destaca a esfera política da obra do dramaturgo. Já aquele, por sua vez, ressalta a premissa dissonante do teatro de Pena, que de modo visionário expunha com acuidade os caracteres de uma sociedade patrimonialista e, ao mesmo tempo, sediciosa.

A título de ilustração e desenvolvimento da reflexão, vejamos a passagem abaixo de $O$ Noviço, peça de 1845: 
Carlos, com hábito de noviço, entra assustado e fecha a porta.

EMÍLIA, assustando-se - Ah, quem é? Carlos!

CARLOS - Cala-te!

EMÍLIA - Meu Deus, o que tens, por que estás tão assustado? O que foi? [...]

CARLOS - Fugi do convento, e aí vêm eles atrás de mim.

EMÍLIA - Fugiste? E por que motivo?

CARLOS - Por que motivo? Pois faltam motivos para se fugir de um convento? O último foi o jejum em que vivo há sete dias... Vê como tenho esta barriga, vai a sumir-se. Desde sexta-feira passada que não mastigo pedaço que valha a pena. [...]

CARLOS - Seis meses de martírio! Não que a vida de frade seja má; boa é ela para quem a sabe gozar e que para ela nasceu; mas eu, priminha, eu que tenho para a tal vidinha negação completa, não posso!

EMÍLIA - E os nossos parentes quando nos obrigam a seguir uma carreira para a qual não temos inclinação alguma, dizem que o tempo acostumar-nos-á.

CARLOS - O tempo acostumar! Eis aí porque vemos entre nós tantos absurdos e disparates. Este tem jeito para sapateiro: pois vá estudar medicina... Excelente médico! Aquele tem inclinação para cômico: pois não senhor, será político... Ora, ainda isso vá [...]. Aqueloutro chama-lhe toda a propensão para a ladroeira; manda o bom senso que se corrija o sujeitinho, mas isso não se faz: seja tesoureiro de repartição, fiscal, e lá se vão os cofres da nação à garra... Essoutro tem uma grande carga de preguiça e indolência e só serviria para leigo de convento, no entanto, vemos o bom do mandrião empregado público, comendo com as mãos encruzadas sobre a pança o pingue ordenado da nação.

EMÍLIA - Tens muita razão; assim é.

CARLOS - Este nasceu para poeta ou escritor, com uma imaginação fogosa e independente, capaz de grandes coisas, mas não pode seguir a sua inclinação, porque poetas e escritores morrem de miséria, no Brasil. E assim o obriga a necessidade a ser o mais somenos amanuense em uma repartição pública e a copiar cinco horas por dia os mais soníferos papéis. O que acontece? Em breve matam-lhe a inteligência e fazem do homem pensante máquina estúpida, e assim se gasta uma vida! É preciso, é já tempo que alguém olhe para isso, e alguém que possa.

EMÍLIA - Quem pode nem sempre sabe o que se passa entre nós, para poder remediar; é preciso falar.

CARLOS - O respeito e a modéstia prendem muitas línguas, mas lá vem um dia que a voz da razão se faz ouvir, e tanto mais forte quanto mais comprimida. (Pena, 2007, p. 89 $-91)$.

O trecho apresentado foi extraído do Primeiro Ato, Cena VII, de uma das peças mais populares do autor. $O$ Noviço, comédia em três atos escrita e encenada em 1845, narra a trajetória de Carlos, jovem encaminhado para o convento por sua tia e tutora, Florência. Essa, por sua vez, é uma viúva rica e ingênua casada com o inescrupuloso Ambrósio, sujeito interessado basicamente no dinheiro de Florência. A fim de se apossar da fortuna da viúva, Ambrósio procura afastar do convívio familiar Juca, o filho caçula, Emília, a primogênita, e Carlos, o sobrinho tutelado por Florência. O ardiloso marido usa da nobreza contida na suposta vocação religiosa para tentar promover a alienação parental dos filhos e sobrinho da viúva, para assim se apossar do dinheiro sem empecilhos. Entretanto, os planos de Ambrósio começam a ruir com a chegada de sua primeira mulher, Rosa, vinda do Nordeste. A partir de um enredo trivial temperado pela comédia o dramaturgo traz para o proscênio críticas sociais 
absolutamente relevantes, dissonantes em relação à agenda literária do período e ainda bastante atuais.

No curto trecho da cena apresentada, vemos a um só tempo críticas contundentes as instituições clericais: "Por que motivo? Pois faltam motivos para se fugir de um convento?". As farpas também são direcionadas para os atores políticos do passado - o apontamento também tem validade no presente, pois pouca coisa mudou de lá para cá -: "Aquele tem inclinação para cômico: pois não senhor, será político... Ora, ainda isso vá [...]”. O serviço público, claro, também não foi poupado das severas críticas. Este, tanto no passado quanto no presente segue dando mostras vigorosas de como a coisa pública serve pouco a quem, de fato, se destina: "Aqueloutro chama-lhe toda a propensão para a ladroeira; manda o bom senso que se corrija o sujeitinho, mas isso não se faz: seja tesoureiro de repartição, fiscal, e lá se vão os cofres da nação à garra..." É impressionante o vigor com que $O$ noviço chega aos dias de hoje. Já em 1845 a sagacidade do dramaturgo Martins Pena foi capaz de colocar na boca de sua personagem o desapego pela cultura e a extrema dificuldade de se viver de Arte em um país como o Brasil. A consequência disso é uma existência anêmica e esquálida: "Este nasceu para poeta ou escritor, [...] mas não pode seguir a sua inclinação, porque poetas e escritores morrem de miséria, no Brasil. E assim o obriga a necessidade a ser [...] amanuense em uma repartição pública e a copiar cinco horas por dia os mais soníferos papéis. [...] Em breve matam-lhe a inteligência e fazem do homem pensante máquina estúpida, e assim se gasta uma vida!". Como se pode ver, especialmente aos olhos de hoje, o teatro de Martins Pena exala uma potência contestatória e política inegáveis. Tal potência, juntamente com a sagacidade narrativa e a força cênica da obra reforçam o imperativo de se trabalhar com obras teatrais tanto no âmbito dos cursos de Letras, como na realidade das escolas de Ensino Básico do país.

Seguindo em nossa análise dessa amostra significativa da dramaturgia nacional e a possibilidade de melhor conhecermos o país através dos textos criados para os palcos, trago agora para exame a peça Auto da compadecida, de Ariano Suassuna. Esta é seguramente a obra do dramaturgo mais conhecida pelo grande público e uma das mais encenadas de todo seu repertório. Texto escrito em 1955 e encenado pela primeira vez em 11 de setembro de 1956, em Recife, no Teatro Santa Isabel, pelo Teatro Adolescente do Recife, sob a direção de Clênio Wanderley. Bárbara Heliodora em texto publicado no jornal O Globo em 23 de julho de 2014, por ocasião da morte do escritor, afirmou ser o "Auto da compadecida, um dos raríssimos clássicos da dramaturgia brasileira [...] sua importância é imensa, e nenhuma outra obra teatral brasileira tem o alcance dela em termos de comunicação com o público". (Heliodora, 2014, p. 1). O juízo da eminente crítica não deixa dúvidas de que estamos diante de um dos mais importantes textos teatrais brasileiros de todos os tempos e, seguramente, ele muito tem a nos comunicar sobre o país.

Sobre a construção de Auto da compadecida, assim se pronuncia a professora e pesquisadora Irley Machado:

Para a construção do Auto da compadecida, Ariano Suassuna recorreu a uma tradição cômica bastante viva que ele domina admiravelmente. $\mathrm{O}$ autor possui o mérito de transformar a literatura oral e popular do Nordeste e dar-lhe formas novas, que lhe preservam a autenticidade. Usamos a palavra tradição, pois é-nos difícil precisar e diferenciar com exatidão a origem das histórias que o autor insere em sua obra e as histórias que ele mesmo cria. A história do "testamento do cachorro", que serve ao desenvolvimento do primeiro episódio do Auto da compadecida, encontra sua origem numa lenda oriental do século $\mathrm{V}$, mas ela está presente também no romanceiro da região e Suassuna deu-lhe cores bem originais. (Machado, 2008, p. 113) 
A apreciação da pesquisadora identifica muito claramente o acento sobre a cultura oral popular que serviu de importante fundamentação para a criação da peça. O próprio Suassuna enfatizava a mirada popular de seu trabalho, destacando a importância de determinados elementos, tais como: os folhetos da literatura de cordel, os improvisos dos cantadores, os contos e recontos da tradição oral, os espetáculos populares como por exemplo, o bumba-meuboi e o mamulengo. As obras do dramaturgo, além de beberem dessa fonte popular também se alimentaram da tradição erudita. Não se pode esquecer da face de professor de Estética do autor, com importante livro publicado sobre o tema. Com relação à fusão entre o popular e o erudito na trajetória de Suassuna, a crítica Bárbara Heliodora faz uma consideração precisa:

Ariano Suassuna é a prova de que uma cultura vasta e o conhecimento das grandes tradições da arte ocidental parecem ser a melhor base para a criação de uma obra essencialmente brasileira; nascido e criado no nordeste, sua obra dramática foi desde o início influenciada tanto pelo teatro de mamulengos e pela literatura de cordel, quanto por tudo que ele conhecia do teatro universal; e com o tempo Suassuna se dedicou fundamentalmente àquelas expressões de suas origens, integrando-as com as formas eruditas que the pareciam ser o melhor caminho para se conseguir estabelecer uma comunicação plena entre a riqueza regional e o total do Brasil contemporâneo. (Heliodora, 2014, p. 1)

O que parece ser no caso, por exemplo, de Auto da compadecida um texto fruto de uma espontaneidade ingênua é, na realidade, um trabalho intelectual apurado em que o preparo erudito do autor não nega as bases populares de suas origens. Suassuna constrói uma obra sólida em decorrência da sua capacidade de transitar entre o erudito e o popular sem, necessariamente, hierarquizar esses polos. O local e o regional se encontram no teatro de Suassuna com vistas ao universal, sempre mediado pelas questões fulcrais dos seres humanos. Sem proselitismos de quaisquer ordens, o autor consegue uma forma teatral poética potente e que encontra no riso sua mola mestra. Mas, não se trata do riso tolo, por constrangimento ou aquele provocado por situações de medo ou desespero. O riso nas obras do dramaturgo é a um só tempo provocador, inquietante e libertador porque se presta a desestabilizar a ordem social e existencial.

A respeito do riso Irley Machado, na continuidade de seu artigo, faz as seguintes considerações:

A proposição mais séria que Suassuna nos faz é rir. É preciso rir desta natureza humana cuja credulidade e ingenuidade a fazem perder a consciência dos próprios defeitos. Pelo riso o homem toma consciência dele mesmo, liberando-se de suas angústias existenciais. Mas como poeta cômico, Suassuna também quer fazer refletir. Se o riso pode ser determinante nas reações, é o pensamento que pode auxiliar a compreender a verdade humana que se oculta atrás do riso. O riso denuncia o real, o suaviza, para enfim, exorcizálo. (Machado, 2008, p. 119)

João Grilo, Chicó, Padre João, o padeiro, a mulher do padeiro, Antônio Moraes, o Bispo e todas as demais personagens dessa ciranda do riso que é a narrativa do Auto da compadecida estão a serviço da provocação do pensamento. Cena após cena o leitor/espectador vê suas crenças monolíticas sofrem fissuras. Verdadeiros abalos sísmicos implodem as certezas e a autoindulgência que insistem em emparedar a experiência humana numa espécie de operação aritmética redutora das possibilidades dos indivíduos. Na medida que a leitura/exibição da peça avança, somos capturados pelo ritmo dessa ciranda que nos convida a sair do lugar da seriedade. 
Distraídos, penetrarmos nos domínios do riso e de seus poderosos efeitos de nos levar para o sempre necessário campo da dúvida.

Vejamos como essa encantadora ciranda, já na cena de abertura do espetáculo, quer nos conduzir através do domínio do riso para o campo do questionamento e da relativização das supostas verdades:

Ao abrir o pano, entram todos os atores, com exceção do que vai representar Manuel, como se se tratasse de uma tropa de saltimbancos, correndo, com gestos largos, exibindo-se ao público. Se houver algum ator que saiba caminhar sobre as mãos, deverá entrar assim. Outro trará corneta, na qual dará um alegre toque, anunciando a entrada do grupo. Há de ser uma entrada festiva, na qual as mulheres dão grandes voltas e os atores agradecerão os aplausos, erguendo os braços, como no circo. A atriz que for desempenhar o papel de Nossa Senhora deve vir sem caracterização, para deixar bem claro que, no momento, é somente atriz. Imediatamente após o toque de clarim, o Palhaço anuncia o espetáculo.

Palhaço, em grande voz - Auto da Compadecida! O julgamento de alguns canalhas, entre os quais um sacristão, um padre e um bispo, para exercício da moralidade.

\section{Toque de Clarim.}

Palhaço - A intervenção de Nossa Senhora no momento propício, para triunfo da misericórdia. Auto da Compadecida!

\section{Toque de Clarim.}

A Compadecida - A mulher que vai desempenhar o papel desta excelsa Senhora, declarase indigna de tão alto mister.

\section{Toque de Clarim.}

Palhaço - Ao escrever esta peça, onde combate o mundanismo, praga de sua igreja, o autor quis ser representado por um palhaço, para indicar que sabe, mais do que ninguém, que sua alma é um velho catre, cheio de insensatez e de solércia. Ele não tinha o direito de tocar nesse tema, mas ousou fazê-lo, baseado no espírito popular de sua gente, porque acredita que esse povo sofre e tem direito a certas intimidades.

\section{Toque de Clarim.}

Palhaço - Auto da Compadecida! O ator que vai representar Manuel, isto é, Nosso Senhor Jesus Cristo, declara-se também indigno de tão alto papel, mas não vem agora, porque sua aparição constituirá um grande efeito teatral e o público seria privado desse elemento de surpresa.

\section{Toque de Clarim.}

Palhaço - Auto da Compadecida! Uma história altamente moral e um apelo à misericórdia.

João Grilo - Ele diz "à misericórdia, porque sabe que, se fôssemos julgados pela justiça, toda a nação seria condenada,

Palhaço - Auto da Compadecida! (Cantando.) Tombei, tombei, mandei tombar!

Atores (respondendo ao canto) - Perna fina no meio do mar.

Palhaço - Oi, eu vou li e volto já.

Atores (saindo) - Oi, cabeça de bode não tem que chupar.

Palhaço - $\mathrm{O}$ distinto público imagine à sua direita uma igreja, da qual o centro do palco será o pátio A saída para a rua é à sua esquerda. (Essa fala dará ideia da cena, se se adotar uma encenação mais simplificada e pode ser conservada mesmo que se monte um cenário mais rico.) Aqui pode-se tocar uma música alegre e o Palhaço sai 
dançando. Uma pequena pausa e entram Chicó e João Grilo. (Suassuna. 2004, p. 22 $-25)$.

Lida apressadamente a passagem apresentada pode indicar certa tendência moralizante do texto. Todavia, observado com mais acuidade, o segmento textual que abre o espetáculo está eivado de provocações e ironias. Talvez, a primeira provocação seja a de assumir o caráter circense da montagem. De saída, já na rubrica do autor, podemos encontrar orientações que destacam abertamente a escolha por uma encenação marcada pela mirada circense e, por extensão, afeita ao riso: "Ao abrir o pano, entram todos os atores [...] como se se tratasse de uma tropa de saltimbancos, correndo, com gestos largos, exibindo-se ao público. Se houver algum ator que saiba caminhar sobre as mãos, deverá entrar assim.” (Suassuna, 2004, p 22). A recomendação do trecho destacado não deixa dúvidas sobre o imperativo de os atores se portarem como uma trupe de saltimbancos. Essa designação é muito significativa, sobretudo quando levamos em consideração que a palavra saltimbancos pode ter um caráter pejorativo, mesmo quando utilizada para designar artistas de circo. A presente indicação no texto permite que vejamos a ironia do autor na construção da peça. Por um lado, ele exorta para que se assuma a entonação de saltimbancos. Por outro, já na primeira fala da obra, a personagem do Palhaço - que por si só evoca o riso - adverte que as ações do espetáculo concorrerão para "o exercício da moralidade". Há, visivelmente, nos trechos em análise um jogo de ambiguidades que remontam a desestruturação de qualquer noção de imobilidade narrativa. A presença do elemento popular marcado pela coreografia circense contribui para neutralizar um possível caráter moralista da peça. A tônica popular dos saltimbancos sublinha muito bem o lugar privilegiado da enunciação do discurso na narrativa. Terão lugar, voz e fala na obra aqueles a quem o status quo invariavelmente subtrai dos recursos materiais aos sonhos. Nesse sentido, Auto da compadecida se afigura como um enorme exercício de alegre alteridade.

O escritor Braulio Tavares, em belo texto de apresentação ao Volume 1 do Teatro Completo de Suassuna chama atenção para um ponto próximo ao analisado no presente trabalho:

O teatro de Suassuna pode ter intenções moralizantes, embora possa ser dito também que suas intenções são desmoralizantes acima de tudo: é um teatro de desmascaramento, de desconstrução dos pretensiosos, dos hipócritas, dos arrogantes. O riso que provoca pode ser o da satisfação diante de uma esperteza bem urdida, mas também o riso que comemora a exposição pública das vilanias de um farsante. Não é o riso sobranceiro de um moralista que toma o lugar do outro. (Tavares, 2018, p. 20)

A escolha de uma personagem - espécie de alter ego do autor - com características de um mestre de cerimônias poderia evocar algum tom moralizante para a peça. Afinal de contas, em sentido geral, o papel do mestre de cerimônias é o de ser um anfitrião, responsável pelo bom andamento da solenidade. Em sentido estendido, é aquele que cuida por guardar a moralidade de evento ou situação. Mas, no caso de Auto da compadecida, esse anfitrião assume feições bastante ambíguas: "Ao escrever esta peça, onde combate o mundanismo, praga de sua igreja, o autor quis ser representado por um palhaço, para indicar que sabe, mais do que ninguém, que sua alma é um velho catre, cheio de insensatez e de solércia." (Suassuna, 2004, p. 23). A escolha deliberada do palhaço para representar a figura do autor já relativiza os sentidos de moralidade. O combate ao "mundanismo" será conduzido por um sujeito que personifica a ralé, sempre objeto do escárnio, do riso e da depreciação. Logo, institui-se uma inversão dos polos, ao se elevar o palhaço à condição de mestre de cerimônias. Isso acontece porque ele é objeto do riso e do risível. Dessa maneira, tal condição o credencia a estar ombro a ombro com os preteridos socialmente, os deserdados da ordem social, os que por serem curtidos no sofrimento só têm 
aos céus para elevar suas vozes em busca de amparo. Daí decorre o tal "direito a certas intimidades" adquirido pelos desamparados dos quatro cantos da terra. O riso produzido a partir daí será fruto da afirmação da existência dos mais simples, que clamam por visibilidade e um lugar nesse enorme e desigual país chamado Brasil.

Ler a peça Auto da compadecida afigura-se como uma oportunidade singular de melhor compreender a diversidade cultural e os modos de vida de um país que comporta muitos países num só. Agora, sairemos da realidade solar do Nordeste de Suassuna para o cenário de um morro carioca com seus dramas, esperanças e perplexidades.

Eles não usam Black-tie, de Gianfrancesco Guarnieri encerra a trilogia de peças que ajudam a dimensionar algumas imagens relevantes do país. Obra escrita em 1955, quando o autor contava com apenas 21 anos de idade, e encenada pela primeira vez em 1958, no Teatro de Arena de São Paulo, Eles não usam black-tie é um marco da dramaturgia nacional. Décio de Almeida Prado chama atenção para o fato de a obra ter se destacado nos fecundos anos de 1955 a 1960: "foi ela, contudo, que fícou como marco histórico, seja pelo inesperado e prolongado sucesso de bilheteria que obteve, revertendo em favor das peças nacionais a expectativa do público, seja pela guinada estética e política que significou, ao aproximar duas entidades até então julgadas quase incompatíveis - teatro e povo (Prado, 1993, p. 109). Guarnieri é um dos pioneiros no teatro brasileiro quando o assunto é o protagonismo das classes populares. A trama da peça gira em torno de uma greve operária conduzida por Otávio, "o maior greveiro carioca" (Guarnieri, 2016, p. 61), morador de uma favela repleta de problemáticas sociais e econômicas. A obra ganha em dramaticidade ao apresentar como entrecho principal a situação do jovem operário Tião. Filho do líder grevista, ele fura a greve, à primeira vista, por temor de perder o emprego, justamente no momento em que sua namorada está grávida. Sábato Magaldi assim se pronuncia sobre a obra:

Eles não usam black-tie [...] trouxe para nosso palco os problemas sociais provocados pela industrialização, com o conhecimento das lutas reivindicatórias de melhores salários. O título, de claro propósito panfletário, parecia ingênuo ou de mau gosto, não fosse também o nome da letra de samba que serve de fundo aos três atos. Embora o ambiente seja a favela carioca, o cenário existe apenas como romantização de possível vida comunitária, já que a cidade simbolizava o bracejar do indivíduo só. Nem por isso o tema deixa de ser profundamente urbano, se o considerarmos produto da formação dos grandes centros, e nesse sentido a peça de Gianfrancesco Guarnieri se definia como a mais atual do repertório brasileiro, aquela que penetrava a realidade do tempo com maior agudeza. (Magaldi, 2004, p. 245).

O elemento popular como móvel principal da obra é amplamente destacado pelo crítico. O título da peça que poderia sugerir uma capitulação panfletária do texto acaba se convertendo em afirmação do popular, em decorrência de também dar nome à letra do samba que permeia os três atos do espetáculo, funcionando como uma espécie de coro. A favela, para além de ensejar certa visão romântica dos modos de vida dos mais pobres, pode ser vista também como um ponto de resistência popular e comunal, sobretudo quando comparada com o restante da cidade partida em múltiplos pedaços de solidão. Além disso, a obra de Guarnieri teve também o mérito de trazer para o palco as novas pautas reivindicatórias das classes populares de um país em plena transformação econômica e industrial. Ao apontar a capacidade do jovem dramaturgo de apreensão das questões candentes de seu tempo, Sábato Magaldi iluminava a modernidade estética e política do teatro brasileiro de então. Um teatro que passava o país em revista, além de não ser furtar de esmiuçar os dramas humanos. 
O diálogo a seguir, extraído do Quadro II, do Ato III, põe em relevo não apenas o conflito social do líder grevista desapontado com o companheiro que furou o movimento operário. $\mathrm{O}$ substrato mais profundo da passagem, a meu ver, recai no drama humano do pai que se depara com a atitude do filho que é inversamente proporcional aos valores mais caros ao patriarca. Vejamos:

Tião - Papai...

Otávio - Me desculpe, mas seu pai ainda não chegou. Ele deixou um recado comigo, mandou dizê pra você que ficou muito admirado, que se enganou. E pediu para você tomá outro rumo, porque essa não é casa de fura-greve!

Tião - Eu vinha me despedir e dizer só uma coisa: não foi por covardia!

Otávio - Seu pai me falou sobre isso. Ele também procura acreditá que num foi por covardia. Ele acha que você até que teve peito. Furou a greve e disse pra todo mundo, não fez segredo. Não fez como o Jesuíno que furou a greve sabendo que tava errado. Ele acha, o seu pai, que você é ainda mais filho da mãe! Que você é um traidô dos seus companheiro e da sua classe, mas um traidô por convicção!

Tião - Eu queria que o senhor desse um recado a meu pai...

Otávio - Vá dizendo.

Tião - Que o filho dele não é um "filho da mãe". Que o filho dele gosta de sua gente, mas que o filho dele tinha um problema e quis resovê esse problema de maneira mais segura. Que o filho é um homem que quer bem!

Otávio - Seu pai vai ficar irritado com esse recado, mas eu digo. Seu pai tem outro recado pra você. Seu pai acha que a culpa de pensá desse jeito não é só sua. Seu pai acha que tem culpa...

Tião - Diga a meu pai que ele não tem culpa nenhuma.

Otávio (perdendo o controle) - Se eu tivesse educado mais firme, se te tivesse mostrado melhor o que é a vida, tu não pensaria em não ter confiança na tua gente...

Tião - Meu pai não tem culpa. Ele fez o que devia. O problema é que eu não podia arriscá nada. Preferi tê o desprezo de meu pessoal pra poder querer bem, como eu quero querer, a tá arriscando a vê minha mulhé sofrê como minha mãe sofre, como todo mundo nesse morro sofre.

Otávio - Seu pai acha que tem culpa!

Tião - Tem culpa de nada, pai!

Otávio (num rompante) - E deixa ele acreditá nisso, se não, ele vai sofrê muito mais. Vai achar que o filho dele caiu na merda sozinho. Vai achar que o filho dele é safado de nascença. (Acalma-se repentinamente.) Seu pai manda mais um recado. Diz que você não precisa aparecê mais. E deseja boa sorte pra você.

Tião - Diga a ele que vai ser assim. Não foi por covardia e não me arrependo de nada. Até um dia. (Encaminha-se para a porta). (Guarnieri, 2016, p.101 - 103)

O quadro é dramaturgicamente muito bem elaborado. O diálogo empreendido entre pai e filho é desenvolvido a partir de um processo de distanciamento interpessoal que marca o ponto crucial da ruptura entre ambos. A estratégia de colocar a personagem de Otávio falando sobre si em terceira pessoa acentua o efeito de sentido de afastamento entre as personagens. Além disso, tal expediente pode ser também entendido como um recurso de resistência ao sofrimento imposto pela ação do filho. Uma espécie de tentativa desencantada do pai de compreender as razões do filho. Tião, por sua vez, aceita esse pacto de distanciamento como uma espécie de último recurso para expor suas motivações ao patriarca. A fatura dessa opção cênica aponta para um dos momentos crucias da peça, a saber o confronto entre os mundos que forjaram pai 
e filho: o primeiro, calcado numa visão, em certo sentido, idealizada de solidariedade humana, pautada pelos valores coletivos em detrimento das causas pessoais. Já o segundo, funciona como um espelho dos "novos" tempos, em que a tônica dominante recai sobre o exacerbado individualismo, sem possibilidades de pontos de interseções entre o passado e o presente. Ao afirmar que furara a greve não por covardia Tião interdita qualquer possível caminho de reconciliação com o pai. Otávio, por sua vez, em um exercício retórico e semântico chama para si a responsabilidade da escolha do filho: "- Se eu tivesse educado mais firme, se te tivesse mostrado melhor o que é a vida, tu não pensaria em não ter confiança na tua gente...”. Ao agir assim, o pai, apesar da mágoa, tenta deixar o caminho aberto para uma futura reconciliação. Ao reafirmar que o pai não tinha culpa de nada, Tião acentua sua individualidade em relação a Otávio, o que é positivo no que diz respeito a constituição do indivíduo em relação ao outro e ao mundo. Porém, o filho tinha clareza de que isso significava o cruzamento de uma fronteira com pouca ou quase nenhuma possibilidade de volta. A cena é encerrada de modo melancólico, mas com a afirmação da alteridade do filho: "Não foi por covardia e não me arrependo de nada. Até um dia.".

Eles não usam black-tie põe em cena os dramas humanos, mas também nos oferece uma imagem significativa do país que emergia das transformações sociais advindas do processo de industrialização e de urbanização em andamento naquele período. Nesse sentido, o diálogo de Tião e Maria, sua namorada, após a conversa do primeiro com o pai é bastante reveladora:

Maria - Eu acreditei... eu acreditei que tu ia agi direito... Não tinha razão pra brigá com todo mundo... Tu tinha emprego se perdesse aquele... Tu é moço... Tinha o cara do cinema...

Tião (irrita-se cada vez mais. Uma irritação desesperada) - Mariinha, não adiantava nada!... Eu tive... eu tive...

Maria - Medo, medo, medo...

Tião (num grande desabafo) - Medo, está bem Maria, medo!... Eu tive medo sempre!... A história do cinema é mentira! Eu disse porque eu quero sê alguma coisa, eu preciso sê alguma coisa!... Não queria ficá aqui sempre, tá me entendendo? Tá me entendendo? A greve me metia medo. Um medo diferente! Não medo da greve! Medo de sê operário! Medo de não saí nunca mais daqui! Fazê greve é sê mais operário ainda!...

Maria - Sozinho não adianta!... Sozinho tu não resolve nada!... Tá tudo errado! (Guarnieri, 2016, p. 106).

Em um primeiro momento, o leitor/expectador da peça é impelido a acreditar que a preocupação principal de Tião é com a perda do emprego, em um momento delicado como o da gravidez da namorada. Contudo, numa camada mais profunda o grande medo de Tião era permanecer para sempre na condição de operário, mais do que ser demitido, seu medo era jamais ser alguém: “eu preciso sê alguma coisa!... [...] Medo de não saí nunca mais daqui!". A motivação decisiva para não aderir à greve estava centrada na rejeição do universo operário e tudo o que isso implicava. Nesse sentido, a passagem em destaque ajuda a compreender um processo complexo e perverso presente no surto de industrialização brasileira. Tião encarna os milhares de trabalhadores brasileiros treinados para ocupar fundamentalmente o chão das fábricas, entretanto sem uma qualificação educacional ou profissional que lhes assegurassem, de fato, a tão propalada mobilidade social advinda da modernização do país. Ao negar a classe operária, Tião caiu em um limbo social e, ao mesmo tempo, se debatia contra a estagnação e a negação de outra vida que não a sua. Nesse sentido, essa personagem encarna a enorme complexidade que o país vivia no passado, com efeitos desastrosos no presente. Mas, o presente é outro capítulo ainda a ser escrito... 
A incursão nas obras teatrais aqui analisadas dá bem a dimensão de como o teatro nacional ajuda a compreender o país em suas diferentes latitudes. Elas, além de auxiliarem na compreensão do país a partir de novas perspectivas culturais, nos ofereceram também a oportunidade de avaliar a necessidade premente da aproximação do Teatro com a área de Letras. Ademais, espero sinceramente que esse breve passeio pelo universo teatral de Martins Pena, Ariano Suassuna e Gianfrancesco Guarnieri nos inspire a caminhar com esperança e tenacidade em busca de dias melhores nesse país que, no presente, flerta perigosamente com o precipício. Assim, poderemos voltar ao "Clube da Esquina" e entoar a canção: "Perto da noite estou/ O rumo encontro nas pedras/ Encontro de vez, um grande país eu espero/ Espero do fundo da noite chegar/ Mas agora eu quero tomar suas mãos/ Vou buscá-la aonde for/ Venha até a esquina, você não conhece o futuro/ Que tenho nas mãos"(Nascimento \& Borges, 1970, f. 4). Sigamos juntos com Milton e os irmãos Borges em busca desse futuro, sem perder de vista o passado e o agora.

\section{REFERÊNCIAS}

ARÊAS, Vilma Sant'Anna. Na tapera de Santa Cruz: uma leitura de Martins Pena. São Paulo: Martins Fontes, 1987.

FARIA, João Roberto (dir) História do teatro brasileiro: das origens ao teatro profissional da primeira metade do século XX. São Paulo: Perspectiva: Edições SESCSP, 2012, Vol I.

História do teatro brasileiro: do modernismo às tendências contemporâneas. São

Paulo: Perspectiva: Edições SESCSP, 2013, Vol II.

"Estudo da dramaturgia brasileira nos cursos de Letras". In. WEINHARDT, Maria

Helena; SIMON, Luiz Carlos; RODRIGUEZ, Benito Martinez; OLIVEIRA, Silvana; BUENO, Luís \& CARDOZO, Mauricio Mendonça. Ética e estética nos estudos literários. Curitiba/PR: Editora UFPR, 2013. p. $501-512$.

GUARNIERI, Gianfrancesco. Eles não usam black-tie. 30ª ed., Rio de Janeiro: Civilização Brasileira, 2016.

HELIODORA, Bárbara. “Auto da compadecida, um clássico”. O Globo, Rio de Janeiro, 23 Jul. 2014. Disponível em: https://oglobo.globo.com/cultura/livros/artigo-auto-da-compadecida-um-classico13355300. Acesso em 08 fev. 2020.

MACHADO, Irley. "O Auto da compadecida e um personagem extraordinário". In. Urdimento Revista de Estudos em Artes Cênicas Programa de Pós-Graduação em Teatro UDESC. Vol 1, n¹1, Dez 2008, p. 113 - 121.

MAGALDI, Sábato. Panorama do teatro brasileiro. 6a ed., São Paulo Global Editora, 2004. . Moderna dramaturgia brasileira. São Paulo: Perspectiva, 2010. (Estudos; 159).

NASCIMENTO, Milton; BORGES, Lô \& BORGES, Márcio. "Clube da esquina no 1" In. Milton. Rio de Janeiro: EMI-ODEON, 1970, f.4

PENA, Martins. Comédias (1844 - 1845). $2^{a}$ Ed., São Paulo: Martins Fontes, 2007. Coleção Dramaturgos do Brasil.

PRADO, Décio de Almeida. Peças, pessoas, personagens: o teatro brasileiro de Procópio Ferreira a Cacilda Becker. São Paulo: Cia das Letras, 1993.

ROSENFELD. Anatol. O mito e o herói no moderno teatro brasileiro. $2^{\mathrm{a}}$ ed., São Paulo: Perspectiva, 2012. 
Prismas do teatro. $2^{\mathrm{a}}$ ed., São Paulo: Perspectiva, 2008.

Texto/contexto. $4^{\mathrm{a}}$ ed., São Paulo: Perspectiva, 1985.

SUASSUNA, Ariano. Auto da compadecida. 34a ed.,Rio de Janeiro: Agir, 2004.

TAVARES, Bráulio. "O riso rouco do sertão" In. SUASSUNA, Ariano. Teatro completo - Volume 1

- Comédias. Organização: Carlos Newton Júnior. Rio de Janeiro: Editora Nova Fronteira, 2018.

VERÍSSIMO, José. Que é literatura? E Outros escritos. São Paulo: Landy Editora, 2001.

André Dias, Professor do Programa de Pós-Graduação em Estudos de Literatura da UFF, é autor ou coautor de numerosos livros, capítulos e artigos em periódicos, incluindo Literatura e Teatro: Encenações da Existência (Editora da UFF, 2018). A lista completa de publicações encontra-se em http://lattes.cnpq.br/8559644307489174

Submetido em 02/11/2019

Aceito em 20/12/2019 